\title{
SOMETHING NEW OUT OF ARMENIA
}

\author{
MICHAEL WINTERBOTTOM \\ Corpus Christi College, Oxford
}

\begin{abstract}
RESUMO: Neste artigo, pretendo investigar a dependência de Quintiliano para Élio Teon, à luz do conhecido material grego e também do novo material armênio deste. Assim, pretendo mostrar o que se passava numa antiga escola de retórica no estágio anterior ao da declamação; além disso, pretendo lançar novas luzes sobre o "Livro X" de Quintiliano; enfim, pretendo provar que aquilo que o menino aprendia antes de passar à declamação propriamente dita era de máxima importância para a educação dele e tinha um efeito sem igual em tudo quanto ele pudesse escrever em sua vida posterior.
\end{abstract}

PALAVRAS-CHAVE: Quintiliano; Élio Teon; progymnásmata; declamação; educação.

When I retired in 2001, my thoughts, mindful of the demands of ring composition, returned to my earliest topic for research. So my last professorial class concerned the final chapter of Quintilian's Institutio Oratoria, which begins with remarks on the orator's retirement. It is no time for idleness. The old man should, Quintilian thinks, write history, or a legal treatise, or a rhetorical handbook, or something philosophical; and he will go on teaching, his house crowded with the young men seeking advice from the oracle. My retirement has not been much like that. But ring composition has continued, to the extent that I find myself working, with a much younger colleague, Tobias Reinhardt, of Frankfurt and Oxford, on revising for publication my long-ago doctoral thesis, a commentary on the second book of the Institutio. Since I gained my doctorate in 1963, naturally, a good deal has been published that needs to be taken into account in 2004 - but nothing, it seems to me, of more interest and significance than the 1997 Budé of Aelius Theon's Progymnasmata. The text of Theon, as it was known hitherto, stopped abruptly well before its proper end, though the topics of what was lost could be deduced from allusions in what was preserved. But an Armenian version, giving a complete 
text, became known during the last century; and Giancarlo Bolognesi (of the Catholic University of Milan) and Michel Patillon seven years ago produced a Budé edition in which the known Greek is filled out by the new Armenian material, together, fortunately for me, with a French translation. This fine edition points out some, though not all, of the parallels between this new material and Quintilian, whose closeness to Theon had long been recognised. But I think that there is room for further working of this seam, and from (as it were) the Quintilian end. This paper aims to make a start on this task. In the process I shall be trying to establish pecisely what went on in an ancient school of rhetoric at the pre-declamation stage; I shall hope to throw some new light on Quintilian's tenth book; and I shall argue that what a boy learned before he came on to declamation 'proper' was of great importance to his education, and had a disproportionate effect on anything he might write in later life.

I do not need to remind you that Quintilian's Institutio is not constructed like a typical Ars Rhetorica, or handbook of rhetoric. Instead, it takes us through an orator's life, describing and prescribing an educational process that starts in infancy and ends only with death. I say infancy, because it seems to me that in a passage in Book Two (2.4.15) Quintilian is alluding to a method of helping very young children to learn to talk. He seems to say that it is useful, after telling them some simple story, to make them repeat it, first in the same order and then in a different order. We have perhaps here a witness to a personal experience. Quintilian, marrying late, had two children, perhaps in his sixties; and we know from an affecting passage (6 pr. 8) that he was especially close to his younger son, who died at the age of five. As early as that, a child would not have started his formal education; but nothing is more characteristic of Roman educational practice than the close interest displayed by the father. An older child of Quintilian died at the age of nine, after showing great promise (6 pr. 10-11). In his last days, deficiens iamque non noster, he babbled of scholae and litterae. He had, then, already started at the school of a grammaticus, who taught both formal grammar and the understanding of poetry. The age of entry to this school probably varied a good deal from one pupil to another. And equally it is hard to generalise about the age at which a boy would normally pass (if he did pass at all) from the school of the grammaticus to that of the rhetor. But a child who made this transition would seem to have stayed with the rhetor from the age of fifteen, at the very most, to roughly eighteen.

This variation of practice caused difficulties for teachers, and dispute: should the grammaticus or the rhetor teach the so-called progymnasmata, the preliminary rhetorical exercises that are my topic today? The evidence concerning this dispute 
is too complex for me to discuss now. But one thing is obvious. The longer the grammaticus retained a boy, the more tempting he found it to teach him the progymnasmata. For a rhetor like Quintilian this was a deplorable invasion. But he contented himself with a compromise. The grammaticus was to teach the most elementary of the exercises (those named in 1.9); the majority, however, were to be taught by the rhetor - and these Quintilian lists and discusses in 2.4. The corollary of this compromise was that the age of transition should not be too late. Tiresomely, Quintilian specifies no ages. Indeed he asserts that it is not a question of age at all, but of how far the student has progressed: let him go on to the school of the rhetor when he is capable of it ('cum poterit': 2.1.7). What Quintilian says in 2.1 of contemporary Greek practice (by which he may mean the practice of Greek teachers in Rome) is difficult to follow. As for the Greek writers on progymnasmata, they do not raise the problem at all. Theon, like the others, appears to assume that all the progymnasmata will be taught by the rhetor. That is not very far from Quintilian's position; and so far as this paper is concerned, no more need to be said on the matter.

I do not need to discuss the exact relationship of Quintilian and Theon. The Italian scholar Italo Lana was sure that Quintilian had read, and drawn on, the Progymnasmata. If he had not, he had surely read something very like them (I mention in passing that Malcolm Heath has recently argued that Theon wrote centuries later than Quintilian). Nor do I need to discuss the complications of the ordering of the exercises as laid down in Quintilian and Theon. Both took the sensible view that easier exercises should come before more difficult ones. But they seem to have disagreed on the way in which this principle should be applied. This matters not at all for my purposes. For I shall be concerned not, for the moment, with the individual Exercises (Narration, Theses, Commonplaces, Praise, and the rest), but instead with a group of what I shall call Techniques. Though, as we shall see, they were known to Quintilian, they are discussed systematically only in Theon, whose Budé editors called them 'exercices d'accompagnment'; for whereas the Exercises were taught, one at a time and in succession, pupils were trained in the Techniques throughout the progymnasmatic stage It is the Techniques on which the new 'Armenian' chapters of Theon throw particular light. They are headed (I translate from the French): Reading (c. 13), Listening (c. 14), Paraphrase (c. 15), Elaboration (c. 16), and Contradiction (c. 17).

We had already heard something of these from the Greek version. The

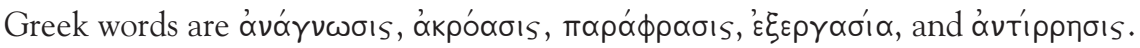
Theon states that 'we shall use Reading, Listening, and Paraphrase from the start, but Elaboration and especially Contradiction only when we have achieved some 
" $\varepsilon \xi \xi_{1 S}$ ' (p. 65 Spengel). I shall return to the implications of this remark about ${ }^{\prime \prime} \xi$ is later. It is not clear from this passage, or any other in Theon, when he thought it had been attained sufficiently to allow the introduction of the Techniques of Elaboration and Contradiction. One assumes, in any case, that the three other Techniques, Reading, Listening and Paraphrase, were taught with increasing sophistication as the course proceeded and the pupil matured.

We may observe that, just as the Technique chapters of Theon follow detailed discussion of the Exercises, so in Quintilian Chapter 2.4 on the Exercises is followed by five chapters of a more general nature. It is from these parts of Quintilian and Theon especially that we may hope to build up some picture of what went on in a rhetorical school at the progymnasmatic stage.

Even the mise-en-scène is problematic. One must apparently visualise the teaching as going on in one, presumably large, room. For when Quintilian (2.2.14) voices his views on the need to keep younger pupils separate from older ones, he says: pueros adulescentibus permixtos sedere non placet mihi, not (perhaps) a natural way of recommending their being placed in different rooms. This reminds us of the wide age range of the pupils concerned. As we have already been told (2.2.3), pupils arrived in the rhetor's school adulti fere pueri, and were still there iunenes etiam facti. Even if pupils attended over an age range of only two or three years, the practical difficulties faced by a single teacher in controlling and organising them, let alone teaching them different parts of the curriculum, must have been formidable. Quintilian does mention the possibility of employing assistants (2.5.3), but not in such terms as to suggest that this was a frequent practice in Roman schools. And with or without them we seem to have to imagine a scene in which, for example, while one age group indulged in tumultuous applause of an effusion of one of their peers (applause much deprecated by Quintilian: 2.2.12), other pupils somehow got on with their work in another part of the room.

Nor is it at all clear how any scope was available in such a system for attention to individual pupils. Yet Quintilian sometimes talks in terms that suggest this was possible. (The problem does not arise for Theon, for he seems to envisage not classroom instruction but the private teaching of a single student.) The teacher's aim, for Quintilian (2.8.4-5) was to observe the strengths and weaknesses of each pupil, and to adapt his teaching to them. Equally, the words secundum cuiusque uires (2.6.5) seem to tell us that the teacher, when providing pre-formed material to his pupils, should make sure that he took account of their different abilities; and in the analogy with the feeding of birds that follows in 2.6.7, the parent birds share 
food out among their nestlings, rather than (the implication should be) leaving it for them to fight for their own portion.

The fifth chapter of book 2 is relevant to this problem of attention to individual pupils, while also forcing us to confront the implications of Theon's discussion of Reading. Quintilian tells us (1) that it is valuable for the rhetor to equip his students with the reading of history and oratory in exactly the same way as the grammaticus was expected to provide poetarum enarratio, exposition of the poets. It is typical of the lacunae in our knowledge of ancient educational practice that we are ill-informed precisely how this vital part of the grammatical syllabus was conducted. Indeed, when the most helpful English book on Roman education, that by S.F. Bonner, comes to this matter (Education in Ancient Rome, 225-6), it has to use as primary evidence our chapter of Quintilian on enarratio of prose by the rhetor. Nor is Quintilian himself very lucid. He remarks (2.5.3) that this practice is one that he had himself sometimes adopted. And it was, he says, current in Greek schools (I suppose in Rome), 'but' (I quote) 'rather by means of assistants, for clearly time is not available for teachers themselves legentibus singulis praeire'. What is meant here, apparently, is a procedure by which the teacher gave a model reading of a passage; then each pupil read the passage aloud, either to the teacher or to an assistant. At some point would come exposition of the content, directed to the class as a whole. Quintilian explains (4) that he is not talking, at this progymnasmatic stage, of the sort of 'reading' that might have taken place in the school of grammaticus, with attention given to (for instance) the meanings of individual words. Rather, the rhetor would do something more appropriate to his profession, by pointing out the stylistic virtues and also vices of the passage under discussion. No question, he adds (5), of calling each pupil up to the feet of the master, and 'playing the slave to him' in the reading of whatever text the boy chose. Here Quintilian seems to be especially dismissive of the idea that the text might not be the rhetor's own choice. (We may compare how Theon [c. 14: p. 107] stresses the need for the master alone to choose the topic for his lecture; but the passage is highly obscure.) And one can see that to allow each child to come up with a different text would make exposition on a class basis impossible. But presumably that each should come up to do his own reading of the same text was just what did happen in a class where the employment of assistant teachers (as in Greek schools, or in Quintilian's own occasional practice) provided the time for legentibus singulis praeire to be possible. Quintilian, however, dismisses that idea too for his present purposes; for he is going in 2.5.6 to put forward a compromise solution, one, presumably, that he himself normally employed. 
In the school of the grammaticus the solution may have been to make the class read the (poetic) passage together. This may be what is implied by Seneca the Elder's reference (Suasoriae 2.13) to a group of people speaking singuli as opposed to omnes simul [but semel is transmitted] tamquam in choro manum ducente grammatico, 'individually, not all together like a choir with the grammaticus conducting'. But the passage may well bear a different interpretation. Again, Macrobius (Sat. 1.24.5) speaks of Virgilian verses qualiter eos pueri magistris praelegentibus canebamus, which ties the occasion down to enarratio poetarum without making it absolutely clear that the 'singing' was done by a group in unison. In any case, Quintilian does not mention such a solution. In any case, Quintilian does not mention such a solution. Instead, he recommends (2.5.6) choosing one of the pupils (turn and turn about) to act as the reader for the occasion. That would give all the pupils the chance to perform, and in the process to get practice also in pronuntiatio, which would doubtless cover gesture as well as vocal effects. This combination of reading with practice in delivery is found also in Theon (c. 13: p. 103); the Budé editors suggest that this shows that the boy read from a book supported on a lectern; but it is possible that Theon is here thinking, as a little further on and in a different context (p. 105), of recitation from memory. As for Quintilian, even though in 2.5 he talks in terms of 'reading', an earlier passage (1.11.14) makes matters much clearer:

when the time comes to read orations, and the pupil is beginning to appreciate their virtues, he must be supervised by a careful and experienced teacher, who will not just train him in reading, but make him learn by heart chosen passages from the speeches, and speak them on his feet, clearly and in the same manner he will eventually have to adopt in court, thus training delivery, voice and memory at one and the same time.

In precisely the same way, Theon speaks of the teacher telling the pupil to learn off examples from literature of the exercises being worked (c. 2, pp. 65-6 Spengel; cf. an obscure passage at the end of c. 13). Another relevant passage is Juvenal 7.152-4, where a big class quaecumque sedens modo legerat, haec eadem stans / perferet atque eadem cantabit uersibus isdem; but this raises too many complications to be discussed here.

The way the master should conduct his enarratio is laid down in 2.5.7-12. We should notice carefully the terms in which Quintilian makes his first point. The reader once chosen, tum exposita causa in quam scripta legetur oratio (nam sic 
clarius quae dicentur intellegi poterunt). The future tenses here (especially legetur) seem to show that this exposition of the circumstances of the case from which the passage is extracted is meant to precede the reading itself. Are we then to suppose that the whole enarratio, the identification of the virtues (and the faults) of the passage in question (as described in 7-12), is also to precede the reading? Quintilian does not say so specifically, while the discussion in Theon (c. 13) does not seem to refer to a classroom situation at all, but (as we have seen) to private instruction of a single student. It may perhaps be that Quintilian, who is after all talking about something whose details he and his Roman readers knew very well, is giving us highlights of a more complex procedure that may have gone like this. The teacher dictates the passage to his group. They copy it down on their tablets or papyrus sheets, and take it away to study at home over night. Next day the teacher appoints the reader for the day, and does his exposition. Finally, the pupil reads, or recites, the passage. This is entirely conjectural. But a student listening to the reading would be able, on this hypothesis, to recognise the features he had been told to look for, and understand better a passage that he might have found puzzling during his work at home the evening before. One might compare the process by which we might read a portion of an unfamiliar classical text, then study a good commentary, and finally re-read the text.

I have talked of a 'passage' being read in this way in a rhetorical school, with the implication that it would not be a particularly long one. We have seen that 1.11 .14 talks of parts chosen from speeches. Yet Quintilian does not in 2.5 speak in such terms. He talks (7), as we have seen, of the oratio to be read (he does not return to the alternative of history until much later in the chapter, at 19), and he recommends the teacher to comment on details that would span a whole speech, from proem to epilogue, and on a whole variety of tones. But one might have expected that Reading would be tied in with the particular Exercise currently being studied. Thus, if the Exercise were the Commonplace, and the subject pro amore (see Quintilian 2.4.23), it would make sense for the class to read a portion of Cicero's speech for Caelius. But Theon too, like Quintilian, talks in c. 13 in terms of a whole speech. It is true, however, that in c. 2 he has given parallels to the various Exercises that take the form of extracts from prose texts, Plato, Herodotus and the like.

Practicality alone would suggest that the model of an extracted passage is preferable. It is beyond belief that a class could, at one sitting, listen to even a short speech of, say, Cicero, together with an exposition of its virtues. We might, of course, conjecture that, as the year went by in practice of the various Exercises, 
the separate sessions devoted to Reading dealt with extended texts, a little at a time; rather as in England today an A-level class might read a book of Virgil over a period of some months, in two or three lessons each week. But one feels that, if this system had been adopted in antiquity, it would have unduly narrowed the range of texts introduced to the pupils (as indeed it does in England. Selection, not just of authors but of passages within authors, seems the natural way of proceeding, and that indeed seems to be hinted at later on in Quintilian's chapter (2.5.24-5), as well as being clearly stated in 1.11.14. If that is right, it looks as though we must understand Quintilian 2.5.7-12 as providing general headings for a commentary from which the teacher would choose what was appropriate on any given occasion. Thus if (for example) the proem of Cicero's Pro Caelio were being studied, the teacher would describe the circumstances of the case, discuss the tone of the passage, and show how it lays the basis for the argumentative strategy of the whole speech. Theon's remarks in c. 13 should perhaps, then, be taken in the same way.

Quintilian 2.5 finds other parallels in Theon's chapters on what I have called Techniques. These suggest (as usual) a close connection between the two authors, or at least a convergence of Roman and Greek didactic practice. I note three instances in particular. Quintilian's remarks (16) on the 'correction' of a published speech of a distinguished author (so much more agreeable to everyone than the correction of a pupil's efforts) should be seen in the light of Theon's chapter (c. 17) on Contradiction, where the pupil is 'invited' to contradict the arguments found in a written text; the example given is from Demosthenes. Second, the authors to be studied: just as Quintilian (19) recommends, among the historians, Livy rather than Sallust for the youngest (doubtless with the implication that Sallust could be read by older pupils), so Theon (c. 13: p. 104) mentions first Herodotus, with his style d'une grande simplicité, then Theopompus and Xenophon, Philistus and Ephorus, and finally Thucydides, whose obscurity Theon goes on to stress. Quintilian's equation of Livy with Herodotus, and of Sallust with Thucydides, seen also in Book 10 (10.1.101), is obvious. Finally, just as Theon (c. 13: p. 105) remarks that imitation of Lysias alone will make pupils indigents, faibles et sans grâce, so Quintilian (21) warns against excessive concentration on reading the old orators like Cato and the Gracchi, for pupils thus fient [...] horridi atque ieiuni. The harm caused by concentration on a single model is also stressed in Quintilian's chapter on imitation (10.2.23-6).

This process, the enarratio of prose authors, is explicitly modelled on the grammaticus's explanation of poetic texts. We are not surprised therefore to find 
parallels to Quintilian's recommendations here in his earlier discussion of the task of the grammaticus (1.8.16-17), who will 'imprint' (infigat: I will return to this metaphor) on the minds of his pupils the various virtues and technical devices of the poetry they are studying. It is interesting, too, to find echoes when Quintilian comes, in Book 10, to give advice to students who have reached an advanced level. He there tells us what this older reader should look for, in terms similar to those used in laying down the sort of thing a rhetor should point out to his pupils. Thus (10.1.22) a reader should be acquainted with the cases in connection with which the speeches he reads were spoken. And in 10.2, the chapter on imitation, Quintilian makes the point (27) that a model is to be followed not just in vocabulary but in the whole conduct of a speech; one needs to pay close attention to the strategies of the speech and to its emotional effect. Thus in childhood the grammaticus and rhetor taught a student to look for certain features of a text he read; when he is older, he is able to look for them himself. I shall come back later to some other aspects of Book 10.

Such is Quintilian's conviction of the value of reading that he compares it very favourably with anything a teacher can provide in the way of a spoken model. He asks (2.5.16): 'if the teacher declaims to provide his pupils with models, will not reading Cicero and Demosthenes make a bigger contribution?' Earlier, true, he has said (2.2.8) that 'though plenty of examples for imitation accrue from reading, more satisfying nourishment comes from the "living voice" of the teacher'. Any contradiction is explained by the context of the two passages, and Quintilian surely did not mean to depreciate the value of models provided by the rhetor's own oral efforts. And we may now turn to the part these played in the schoolroom.

'Ipse aliquid, immo multa cotidie dicat quae secum auditores referant' (2.2.8): the teacher should make formal 'speeches' every day. Similarly Theon (c. 14: p. 107) speaks of 'daily Listening', just as earlier (p. 62 Spengel) he had spoken of daily writing in association with Listening [note also Cic. Brut. 305]. And the pupils, Quintilian says, are to take such speeches back home with them, not, I think, metaphorically, but in the form of notes in which the master's words, or some of them, were taken down. Quintilian talks elsewhere (2.4.12) of different methods of correcting a boy's (I suppose written) work. The teacher may make alterations, sometimes interposing something of his own. Or he may 'dictate' a whole exercise, so that a boy can imitate it and 'love' it until he can produce something good for himself (the use of the word puer reminds us that Quintilian is here thinking of the progymnasmatic stage). But a more regular practice would have been for the teacher to speak a model exercise to the class. This certainly happened at the later full- 
declamation stage, as we know from several passages. One is 2.5.16, which I mentioned earlier. Another is 2.6.1, where one method is to supply a whole speech, complete with argument and emotional appeal, as opposed to a mere 'division', the bare headings of a speech. (Quintilian here seems, rather disconcertingly in the context of these chapters, to be talking in terms not of the progymnasmata, but of the declamations that were taught after them; but I take it that what he says can be taken to apply, mutatis mutandis, to progymnasmatic exercises also.) All this, of course, went on in the privacy of the schoolroom, and is to be distinguished from the display speeches that a master might give in public, to advertise his school and show off his talents.

This sort of thing goes back to the very roots of declamation: to the speeches given by the Greek sophists when teaching their pupils. The aim, as ever, was to provide a model for imitation. Isocrates, in a striking passage (13.18) adduced by Theon's Budé editors, says that it is essential that a teacher should present himself

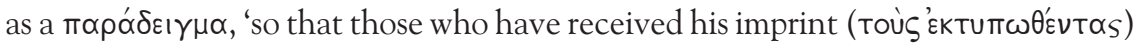
and are capable of imitating him may at once become more accomplished orators than the others'. That terminology continues into Theon: thus (p. 61 Spengel)

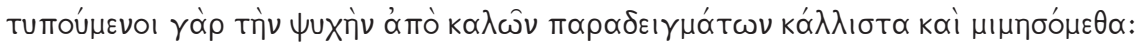
'for if our souls receive the stamp of good examples, we will imitate in the best possible way'; compare (pp. 70-1 Spengel) öா

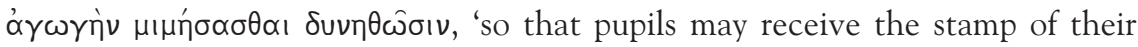
teachers' models and be able to imitate them', and perhaps, from the Armenian [c. 13: p. 105], lorsque quelqu'un admire ce qu'il y a de bon chez tous et entreprend d'y conformer sa pensée, du fait qu' il existe en lui une sorte de matrice du discours, que chacun peut modeler d'après sa propre nature. And this is Quintilian's imagery too. He remarks that, by learning off pieces of oratory or history, pupils 'will always have within them something to imitate', et iam non sentientes formam orationis illam quam mente penitus acceperint expriment (2.7.3). The pupil was 'stamped' with the imprint of the models his teacher provided orally, or by what he read, aloud or in private, from authoritative texts.

The teacher then gives his model, let us say of a Narration. In, for instance, the Libanian collection, the topic would be taken from myth. For Quintilian that sort of Narration would be the province of the grammaticus; he wishes the rhetor to start with stories taken from history. (Of course, history might have more than a touch of myth: when Quintilian comes on to the exercise of refuting Narrations, he gives the example of the wolf that suckled Romulus [2.4.19]. But that story was to be found in the historian Livy.) The master would give a model speech, telling the story. If there was, as I have suggested, some attempt to gear Reading to the 
Exercise currently being taught, the associated lesson in Reading might be that very passage of Livy, or some other from the same author; that would be appropriate in another way, for Quintilian (we recall) approved of the reading of Livy by the young, that open and accessible writer (2.5.19).

Finally: 'I want', says Quintilian (2.4.15) 'Narrations to be composed in writing, with all possible care.' We may imagine then that, after the teacher has spoken his model Narration, the pupil takes home notes of what had been said, and with their help, excogitates a written narrative of his own.

This brings me to a mysterious chapter in the 'Armenian' part of Theon, that concerning Listening (c. 14). This is how I translate ákpó $\sigma \sigma ı s$, for, like the names of the other Techniques, the word refers primarily to an activity of the student. But ákpóaoıs may also mean what the student listens to, something spoken by the teacher. Now, at the start of the chapter, Theon tells us how, by stages, a pupil may come to be able to recall (for example) every detail of the style, content and structure of an oratorical composition that he has listened to. The point of this process of recollection, it emerges, is that the student should be able to reproduce what he has heard, not orally, but in writing. Theon seems to be talking of what we think of as a declamation. And, as usual, he talks in terms of a complete speech. But, granted that the Technique of Listening was inculcated throughout the progymnasmatic course, it may be that what Theon says needs to be understood to cover also the sort of case to which I referred above: the teacher gives a model Narration, orally. The student, having listened to it, works to internalise it in the way described by Theon, and reproduces it in writing. (I earlier made a similar suggestion about the precepts of Theon (and Quintilian too) concerning the enarratio of prose texts: that, though they are framed in terms of complete texts, they may be thought of as applicable to parts of those texts.)

The later part of Theon's chapter on Listening is very obscure, as his editors frankly acknowledge. Clear enough is the notion that, 'if there is no Listening', i.e. if the teacher gives no oral presentation, the pupil will instead be asked to write on a topic suggested by, for example, some recent event, a procession, perhaps, or a spectacle. But what are we to make of the paragraph in which Theon talks of certain works that have been wrongly attributed to famous authors? I can only suggest that there is a lacuna before this paragraph, in which has been lost a transition to a different sort of lecture, in which the master did not declaim, but talked about literary topics connected with prose literature. Robert Kaster, in his lucid way, remarks in his Suetonius commentary (p. 60) that 'as an orator's ókpóools 
would be a "declamation" ... or a poet's a "recitation" ..., a gramm(aticus)'s would be a "lecture" or some similar display of his expertise'. It may then be that Theon, like Quintilian, thinks of the rhetor extending to prose the sort of treatment that a grammaticus gave to poetry, and that this treatment might sometimes take the form of a lecture on the authenticity of a prose text. For that, of course, was what a grammaticus, exercising his крıтıкń, might do for a poetic text. But what the following paragraph may mean, I have little idea, and I will not discuss it now, except to repeat the important new information that Listening occurred every day.

To return to Quintilian: What happened after the pupil had written his little effort following the model of his teacher? It would be natural to expect that the pupil would read his effort out in class, or even memorise it and recite it. And perhaps indeed he sometimes did, even in Quintilian's class (Theon does not help on this topic), no doubt with appropriate measures to discourage the other pupils applauding in the unseemly way described at 2.2.11. And the passage I have mentioned about the teacher's correction of a pupil's exercise (2.4.12) might after all concern the oral and public criticism of a spoken exercise. Clearer is the evidence of 2.7.1, where we find disapproval of the custom by which pupil learned by heart everything (sic) he had written in order to speak it on a formal occasion, perhaps in the presence of the fathers who are said to have insisted on such displays. Quintilian's policy was to restrict this sort of thing, to make sure that only worthy pieces of composition were thus publicised. We may, incidentally, observe the phrasing of this concession: aliquando tamen permittendum quae ipsi scripserint dicere (2.7.5). The implication is perhaps that pupils could and should recite what other people had written; and this seems to take us back to the practice of Reading, where (as we have seen) a pupil read aloud a passage from an established author. And the emphasis in this chapter on the desirability of a pupil learning by heart not his own work but that of classic authors fits in with my earlier assumption that in Reading the pupil learned the passage by heart and recited it, with appropriate gestures.

In any case, it is clear that Quintilian was thoroughly in favour of his pupils learning passages of prose, and he gives cogent reasons for this favour (2.7.2-4, supplemented by 1.11.14): such learning exercised the memory, and provided the internal forma for imitation which I mentioned earlier. And later (10.1.105) Quintilian remarks that he thinks Demosthenes is to be 'read or rather learned off by heart'. At the very earliest stage he has recommended the memorising of 'chosen passages from the poets' (1.1.36). Prose was more difficult to learn off than poetry (11.2.39); but that only made the practice the more valuable. 
It will be recalled that Theon remarked: 'we shall use Reading, Listening, and Paraphrase from the start, but Elaboration and especially Contradiction only when we have achieved some "ह $\xi$ Is'. As his editors acknowledge, we cannot tell at what point the two last Techniques began to be applied. For Quintilian, however, ${ }^{\prime \prime} \xi$ Is was something not to be attained until a much later stage than the progymnasmata. He does not speak of such established ability, indeed, until the start of Book 10. He says at the opening of that book (10.1.1) that it is debatable what most contributes towards this quality: writing, reading or speaking. And the book contains, amongst other things, chapters on reading (1), writing (how to write, 3; what to write, 5), and the closely associated imitation (2). Amidst all this there is much to remind us of Theon. It seems that Quintilian, entirely approving of the Greek's procedures, felt that they should be extended over a much longer time scale, perhaps even over a life-time. " $\xi^{\prime} \xi$ Is could not possibly be attained early on: far more experience was required.

Naturally, the Techniques are adapted to an older student. Reading is now an entirely private activity, and, as we have seen, the reader must now himself look out for the stylistic features formerly pointed out to him by a teacher. Listening (Quintilian uses the word auditio at 10.1.10) is now attendance not at some lecture, but at a real-life oration. Correction, discussed in 10.4, is neither the process described in 2.4.10-12 (cf. 2.2.7), where a kindly teacher points out errors in a pupil's work, nor yet that seen in Theon c. 17, the Contradiction that dares to find fault in a Demosthenes. Rather, it is the process of going over one's own work and giving it a final polish on the basis of one's mature judgement. But it is in the two chapters on Writing that the echoes of the second book are most obvious. One must write with all care and as much as possible (10.3.2; cf. 2.4.15). Writing is a remedy against 'empty loquacity and words that are born only on the lips' (10.3.2; cf. 2.4 .15 'the garrulity of extemporisation'). Writing stores away treasures of words for future use (10.3.3; cf. 2.7.4). This, and more, from 10.3. In 10.5 , the discussion of what is to be written by those striving for ${ }^{\prime \prime} \xi$ Is (and note that this is still not yet achieved), Quintilian starts with translation from Greek, but soon comes on to Paraphrase, to which Theon had devoted a separate chapter (15) as one of the Techniques. For Quintilian it is something to be applied to poetry, to Latin speeches in a spirit of emulation, even to one's own work. $\mathrm{He}$ remarks strikingly (10.5.8) that the exercise gives us the incentive to look very carefully at a piece of writing, 'not passing it over in casual reading', but weighing up its virtues. This, in fact, is a means of encouraging critical reading of texts. Quintilian had mentioned paraphrase in passing at 1.9.2, as something to be 
applied to a piece of poetry with the aim of abbreviation or ornamentation. This was appropriate at a very early stage of rhetorical education, so early that even Quintilian was happy to leave it to the grammaticus. And Suetonius too mentions it in this context (Gramm. 4.5). Theon, on the other hand, thought it should be taught from the start of the course in progymnasmata. Quintilian (who has not mentioned it in Book 2) now promotes it to an even higher class. It is notable, too, that he associates with it the (thoroughly sophistic) exercise of 'expanding what is by nature brief and amplifying the insignificant' (10.5.11; cf. 1.9.2); he may here be working into his system what Theon (c. 16) had called Elaboration, a Technique that became suitable as the progymnasmatic curriculum progressed, though not right from its start.

As 10.5 goes on, we realise that we are being given a partial reprise of elements of Book 2. We are recommended to write Theses (with the comment that Cicero exercised himself on them even when he was a great man), and to employ the associated exercise of supporting and refuting them (10.5.11). Then come Commonplaces, again with a comment suggesting their utility not just for the older student but even for the mature: 'we know that orators wrote them out' (10.5.12, looking back to 2.1.11). And finally (10.5.14) declamation itself recurs, recommended specifically as something which, if properly exercised, will be of high use 'not just while one is growing up, but when one is the complete orator, already famous in court'. Quintilian is quick to warn that one can spend too long in the declamation school (10.5.17-8; cf. 12.11.15); but he is clear that declamation, like the simpler Exercises that preceded it, continues to be of service as worth writing (and surely also sometimes speaking) right on into adult life.

It should not be assumed that what Quintilian recommends in the Institutio took place in every detail in reality, even in his own school. But that students spent much time and trouble on the progymnasmata, that what they learned at this stage became 'building-blocks' when they came to compose complete declamations (cf. 2.10.2), that even the grown Cicero thought it worthwhile to continue to practice on these lines, all this is beyond question. And I propose to conclude this lecture with some remarks on the wider importance of these exercises, preliminary as they were, yet of fundamental and continuing value.

If we are seeking for traces of the influence of rhetorical education on Latin literature, it is most natural, and most fruitful, to look in speeches: which means, primarily, in the orations of Cicero, but also secondarily, in formal utterances represented in other genres, especially epic and the novel. Particularly important 
here is rhetorical precept on the articulation of a speech. When we try to go further than that, we come up against the problem of the inclusiveness of precept. To remark, for example, that an argument used in a speech in the Metamorphoses can be found catalogued in Quintilian is not to make a great discovery; for Quintilian aims to catalogue as many arguments as possible. It might be more significant if it were not found in Quintilian. Or again: Susanna Morton Braund has shown that certain passages in Juvenal 6 can be assigned to the loci listed by Cicero for the arousal of indignation. Well, they would correspond, wouldn't they? - for those loci are intended to cover as many ways as possible of making a listener angry. Nor, again, is it helpful to say that the various tropes, and figures of word and thought, which one can find in a literary text are 'rhetorical' in the sense that a rhetor inculcated them. The problem of inclusiveness arises here also. It is not easy, perhaps impossible, to express oneself without using tropes and figures; and any trope or figure one does use will probably find its place in the handbooks. In any case, though Quintilian, like the Ad Herennium and the De Oratore, discusses such matters (in Books 8 and 9), they were really the preserve of the grammatici (note 8.5.35). It was part of the task of the grammaticus to point out to his pupils tropes and figures in poetry; and, if Quintilian thought the rhetor should do the same in his exposition of prose texts, that was avowedly parasitic on the practice of the grammatici. Fifteen centuries later, in the English 'grammar school', schoolboys of the Elizabethan period (as Brian Vickers puts it in Classical Rhetoric in English Poetry, 48) were taught 'to know the name, definition and use of a large number of figures of speech'. They would first learn the figures, then identify them in whatever they read, thirdly use them themselves. That is the training that led to the extravagances of early Shakespeare. It is not specifically rhetorical.

To come closer to the rhetor's school: at least some of what we tend to call 'rhetorical' expression or tone in Latin literature might more helpfully be called declamatory. Inclusiveness is relevant here too. Rhetoric, allied with grammar, aimed to classify all means of expression; it would not be absurd to say that everything we write is in some sense 'rhetorical'. But there is a certain tone, especially dominant in post-Augustan literature, that can be reasonably called 'declamatory', a tone that I once described as 'hectic, hectoring and melodramatic'. Such tone expresses itself in paradox, exaggeration, and ingenuity of all kinds; it favours not so much the long period as the short phrase (especially to mark articulation by closure). It is reasonable to suppose that this sort of tone began to impose itself at the progymnasmatic stage, at least where a teacher was so inclined (and, as a few passages in the Institutio show, even Quintilian could write like this 
when he wished to). This is where the model speech was so important: tone and style no less than content.

All the same, it would be difficult for a thirteen- or fourteen-year old to master such a tone quickly. It was surely the content that affected him most profoundly. No age is more impressionable than this. What one learns then stays with one for ever. And, in any case, the content of a boy's later rhetorical studies was of no great relevance if he chose to be a poet or essayist rather than an orator. But the progymnasmata taught him to discourse upon a very wide variety of topics, using techniques that would be relevant later, not merely in declamation or oratory, but in any form of literature. The wide utility of Narration is an obvious example. Inculcated by instances from history, it could feed back into history again. The exercise in Praise not merely provided frameworks (and checklists) for eulogy in other genres; it also, as Quintilian puts it (2.4.20), equipped a pupil with cognitio rerum, and exempla that were indeed in omni genere causarum potentissima, but might illuminate a philosophical point too. (This is perhaps the only point where history in the modern sense was taught.) Quintilian appends to Praise the Comparison of people. The comparison of Milo and Clodius is a Leitmotif of the speech for Milo; but comparison is also vital for a Plutarch writing biography. Then there are Commonplaces, directed, say, against sexual excess. Add a defendant, and this becomes an accusation, says Quintilian (2.4.22); and so Caelius found. But a philosopher like Seneca might use such material too. As for Thesis, Quintilian gives as an example the merits of life in the country as opposed to life in the town (2.4.24). That topic could find a place in declamation, as Decl. Min. 298 shows, or in real-life oratory (Cicero exploits it in his speech for Roscius of Ameria). But it is reflected in literature of many kinds, including satire and didactic. It is hard to think that it does not have some bearing on the tone (and weaknesses) of the closing lines of the first Georgic.

Most influential of all, perhaps, was an exercise found in Theon (though not in Quintilian 2.4). This was Prosopopoeia, where the pupil was asked to imagine 'what sort of words would be spoken' by someone in a particular situation. Other progymnasmatists often give examples from mythology: what would Medea say when Jason married another woman? (Quintilian may well have thought such exercises should be taught by the grammaticus). But Theon's examples draw on real life or on history: what would a husband say to his wife when he was setting off abroad, or Datis to the Great King after the Persian defeat at Marathon? (This type Quintilian seems to have taught at the rather later suasoria stage.) A pupil trained in this exercise could go on successfully to write a declamation in character. 
When grown up, he might be a Cicero, able to give words to Appius Claudius Caecus inveighing against Clodia. But equally he might be an Ovid writing a speech for a mythological character in the Metamorphoses or for a lover in the amatory works; or a Propertius who found in his fourth book that he could widen his scope by the use of a variety of speakers; or a Tacitus writing a speech for the Scottish chieftain Calgacus on the eve of a battle with invading Romans.

In such ways, the progymnasmata left an imprint on a boy's mind, and on his style, that might well last a lifetime. Here, perhaps, more than in the details of rhetorical precept, may lie a crucial part of what we mean when we talk about the influence of rhetorical education on Latin literature.

\begin{tabular}{|l|l|}
\hline THEON & QUINTILIAN \\
exercises: $3-12$ & exercises: 2.4 \\
techniques (only in Armenian version): & \\
reading: 13 & 2.5 \\
listening: 14 & $2.2 .8,2.5 .16,2.6 .1$ \\
paraphrase: 15 & cf. 1.9.2, 10.5.3-8 \\
elaboration: 16 & cf. 1.9.2, 10.5.11 \\
contradiction: 17 & cf. 2.5.16 \\
& enarratio, followed by reading (aloud) \\
& model speeches, followed by writing (and \\
& recitation?) \\
\hline
\end{tabular}

WINTERBOTTOM, M. Something new out of Armenia.

ABSTRACT: This paper aims to examine the closeness of Quintilian to Aelius Theon in the light of the known Greek and also the new Armenian material. In the process I shall be trying to establish precisely what went on in an ancient school of rhetoric at the pre-declamation stage; I shall hope to throw some new light on Quintilian's tenth book; and I shall argue that what a boy learned before he came on to declamation 'proper' 
was of great importance to his education, and had a disproportionate effect on anything he might write in later life.

KEYWORDS: Quintilian; Aelius Theon; progymnasmata; declamation; education. 